\title{
Natural Fiber Waste from Palm Oil Tree: An Overview of Potential Usage for Indonesia's Affordable House Building Materials
}

\author{
Widyarko', Naresworo Nugroho², \\ Dalhar Susanto ${ }^{1}$ \\ ${ }^{1}$ Department of Architecture, Faculty of Engineering, Universitas Indonesia, \\ Depok, Indonesia \\ ${ }^{2}$ Faculty of Forestry and Environment, IPB University (Bogor Agricultural \\ University), Kampus IPB Darmaga, Bogor, Indonesia
}

\author{
Article History \\ Received : 14 December 2020 \\ Accepted : 11 April 2021 \\ Published : 24 April 2021
}

\begin{abstract}
The palm oil plantation in Indonesia is an overgrowing industry that also poses significant environmental waste problems. The industry produces numerous unused biomass wastes such as EFB (Empty Fruit Bunch), PKS (Palm Kernel Shell), tree trunks, fronds, etc. On the other hand, the national housing backlog number in 2019 had reached 7.6 million units. The government had launched several housing programs to tackle this ever-repeating issue. Yet, all of the plans failed to solve the housing shortage. A new approach is needed to provide a cheap, affordable, and more environmentally friendly affordable house. Previous studies proved that palm oil fiber waste could be altered into building materials such as lumber and other biocomposites like particleboard, fiberboard, plywood, etc. Consequently, by using the construction scheme in the $\mathrm{RSH}$ affordable house program released in 2002, palm oil fiber waste should be able to displace conventional wood in most of its parts. That is why there is no reason to halt implementing palm oil fiber waste as building materials, especially to build an affordable house. Therefore, the burden of Indonesia's never-ending housing backlog problems should be eased by converting its over-abundant palm oil fiber waste as its building materials new renewable sources.
\end{abstract}

Keywords: affordable house; alternative materials; bio-composite; palm oil fiber waste

\section{Introduction}

Indonesia is currently the world's largest producer of palm oil. This industry is one of the sectors pushed by the government to play an important role in alleviating the Indonesian economy. As a result, in 2017, the palm oil plantation area had reached 12.3 million ha or twice the number in 2007. The average growth of palm oil plantation area for the period 1970-2017 reached $10.31 \%$ per year (Varkkey, 2012). However, a vastly growing industry will also create more significant environmental

Correspondence: Widyarko

Department of Architecture, Faculty of Engineering, Universitas Indonesia, Depok, Indonesia

E-mail: widyarko.ui@gmail.com waste problems. The globally traded commodities from palm oil derivatives are only CPO (Crude Palm Oil) and PKO (Palm Kernel Oil). Both products only represent less than $30 \%$ of the total weight of Palm oil tree's Fresh Fruit Bunch (FFB). The rest of the $70 \%$ will become unused biomass waste. Furthermore, $10 \%$ of palm oil waste had been reused while the leftover became a residue and contributed to severe environmental problems (Dungani et al., 2016).

On the other hand, Indonesia has another issue, such as inadequate housing for its people. The 2016 government targeted the national housing backlog must reach 6.8 million units by 2019 (PUPR, 2016). But sadly, in 2019, the housing backlog number was recorded at 7.6 million units or missed the target set (PUPR, 
Natural Fiber Waste from Palm Oil Tree: An Overview of Potential Usage for Indonesia's Affordable House Building Materials

Widyarko, Naresworo Nugroho, Dalhar Susanto
2019). Since the Declaration of Independence of Indonesia, the government had launched several housing policies to tackle this issue. Wistfully, all of the programs failed to resolve the housing shortage problem. A new method is needed to provide a cheap, affordable, and more environmentally friendly approach, a house using palm oil's biomass waste as material might be an option. This study aims to uncover the potential of oil palm biomass waste as building materials for Indonesia's affordable housing components.

\section{Methodology}

This paper is not a research article but instead uses a review article method. The review article intends to evaluate, identify research gaps or synthesize previous research-based sources. This approach can also be used to investigate the effect of or relationship between two specific variables (Snyder, 2019). In this case, the variables would be the possible relations of two different topics: Indonesia's affordable housing programs and palm oil industry waste. The discussion begins by examining affordable housing programs in Indonesia regarding history, definitions, and implementation. Secondly, discuss the oil palm fiber waste from the stages of the plantation, production, and its volume as a potential source for building material. The last step discusses previous studies that have addressed the conversion of palm fiber waste as a building material and the possibility of implementing it for affordable houses in Indonesia. In the end, this paper closes with conclusions.

\section{Result and Discussion}

\section{Brief History on Indonesia's Affordable Housing Programs}

The principle of a right housing for everyone has been stated in both the earliest and most fundamental constitution of Indonesia, the Undang Undang Dasar (UUD) 1945. It confirms that the nation must actively involve fulfilling housing for all its inhabitants, including the low-income population. However, the history of Indonesia's attempt to provide housing for everyone had been moving up and down during a different era. In pre-independence Indonesia, The Dutch government tried to standardize Indonesian houses' living space. It was the very first minimum space standard to be enacted toward Indonesian houses. However, the standards invited many objections, mostly from local Indonesian (Susanto, Nuraeny \& Widyarta, 2020). Furthermore, the colonial government, which tended to be 'liberal', gave responsibility to provide public housing to the private investment. As a result, almost no affordable housing was built in this era because it was considered too expensive and too small to make an impact (Kusno, 2012).

During the' Orde Lama' or Old Order regime, affordable housing was considered an example of 'housing of the people', which have been fundamentally socialist ethics that essential for the nation's social and political wellbeing. However, because it had never been considered a driver of economic productivity, the progress of affordable housing had not been widely seen yet in this era (Kusno, 2012). However, in August 1950, a new history was recorded in which the Congress of Healthy Housing for Citizen was held and succeeded in formulating the first minimum human needs in Indonesia. One of the congress's conclusions was for the minimum norm of $36 \mathrm{~m}^{2}$ of house floor area with two bedrooms and an additional pavilion of $17.5 \mathrm{~m}^{2}$ for developing citizenry housing (Pandelaki \& Shiozaki, 2010).

The next period is the 'Orde Baru' or the New Order regime. In this period, the affordable housing development progressed massively. At this time, the housing fulfillment for the lowincome population was considered a state of responsibility and supported with government subsidies (Kusno, 2012). There were two monumental programs that tried to provide affordable housing to the people, Rumah Sederhana (RS) or Simple Houses and Rumah Sangat Sederhana (RSS) or Very Simple Houses. RS, which was founded in 1986 defined as a house that had one room with $12 \mathrm{~m}^{2}$ minimum space and can be extended into a complete house with a minimum space of $36 \mathrm{~m}^{2}$ (Pandelaki \& Shiozaki, 2010). This program is considered auspicious in increasing the productivity of affordable housing from an average of only 6000 units per year in 19731977 climbed to 115,000 units per year in 1989 (PUPR, 2001). However, the massive development of RS turned out to be running only in the short run because, in 1990, the government decided to dismiss subsidies for RS houses based on the condition of state finances at that time. 
As a result, the government issued a new affordable housing program known as Rumah Sangat Sederhana (RSS) or Very Simple House. Unlike RS, RSS houses were regulated by the government to be sold at a price lower than the previous RS house market price. The consequence was a downgrade of materials and structural specifications applied in the house. Its appearance can usually be identified with concrete bricks (batako), no cement plaster wall, and the use of asbestos corrugated roof (Pandelaki \& Shiozaki, 2010). This strategy successfully raised the number of affordable houses built in Indonesia, which reached its peak of 167,000 units built in 1997 .

The last phase was the 'Era Reformasi' or the Reform Era. At this time, Indonesia experienced a prolonged economic crisis, which plummets the affordable housing development with only 26,000 affordable house units built-in 2002. Despite the decline, the government still had time to replace RSS policy with Simple Healthy Houses (RSH) or Healthy Simple House. This house can be easily built using simple materials and construction as long as it follows the government's minimum standards. RSH concept is different from the previous one, focuses on local aspects, especially the use of local materials. In this policy, the government made several types of $\mathrm{RSH}$ based on different materials for different areas of Indonesia: brick house, half brick house, wooden house, and stilt wooden (Pandelaki \& Shiozaki, 2010). The application of local material in RSH was hoped to push down construction costs to make the house more affordable for the lower-income population during the economic recession.

In 2016, the latest affordable housing procurement policy was issued under 'Rumah Masyarakat Berpenghasilan Rendah' (MBR House) or House for Low-Income populations. However, this policy only regulated the financing mechanism. As a result, confusion occurred in several areas because it turned out that banks were still using technical standards issued in 2002 for RSH design (Kompas.com, 2018). Building materials like wood that in 2002 were still abundant currently became scarce in several areas. Some developers did tries to handle this issue by using unmatured wood as building materials. Wood taken from young trees tends to produce low-quality timber that, in the long run, may endanger the building structure's longevity (Susanto \& Widyarko,
2017). Nevertheless, this step did not help alleviate the housing backlog, respectively; many regions in Indonesia have not achieved their housing backlog reduction target. It must be admitted that building materials are only one of many issues faced by Indonesia's affordable houses programs, nevertheless choosing the suitable building materials might help solve these problems.

Therefore, a new study is needed to find new, easily obtainable alternatives materials in affordable housing construction. Oil palm fiber waste then needs to be looked at as possible alternative material.

\section{Palm Oil Tree Fiber Waste and Its Volume Potential}

Oil palm or tropical palm tree consists of many different species. However, most of the world's oil palm plantations, including in Indonesia, use the same oil palm tree species, Elaeis Guineensis. Currently, the only objective of oil palm plantations is to get the primary commodities in the form of Crude Palm Oil (CPO) and Palm Kernel Oil (PKO) (Lubis, 2008). Both products can only be extracted from one of the palm oil tree components, Fresh Fruit Bunch (FFB). Processing FFB into $\mathrm{CPO}$ involves cooking, threshing, digestion, pressing, settling, purification and drying. The pressing process results in a waste product, namely nut/fiber (Lubis, 2008). The following process is the separation of nut and fiber followed by drying, nut cracking, kernel/shell separation, drying pressing, and filtering until PKO is produced (Rivai, 2017 ). Different types of fiber waste will be produced during this process, such as; Empty Fruit Bunch (EFB), Palm Kernel Shell (PKS), Mesocarp Fiber (MF), and Palm Oil Mills Effluent (POME). Other than that, palm oil tree also produces waste that is not related to the extraction process such as trunk and frond. This waste exists because the tree's natural ageing process is not due to the extraction process of CPO or PKO. The flowchart production process in plantations and mills that produce fiber waste can be seen in Figure 1. This study focuses on palm oil fiber waste which focuses on five types of waste classified as fiber, namely, OPT, OPF, PKS, EFB, and MF. The following is an explanation of the origin and characteristics of each palm fiber waste; 
Natural Fiber Waste from Palm Oil Tree: An Overview of Potential Usage for Indonesia's Affordable House Building Materials Widyarko, Naresworo Nugroho, Dalhar Susanto

a. Oil Palm Trunk (OPT). Oil palm is a monocotyl plant, and therefore, it has no cambium. The trees have an average trunk length of about $17-20 \mathrm{~m}$, diameter $60-85 \mathrm{~cm}$, volume $0.9-3 \mathrm{~m} 3$. The oil palm trunk height grows about $45 \mathrm{~cm}$ per year depending on plant age, nutrient availability, soil condition, climate, and plant genetics. Oil palm trunk is produced from old plants' regeneration (2530 years old) classified as old/damaged and unproductive plant.

b. Oil Palm Frond (OPF). Oil palm frond (OPF) is one of the good by-products of oil palm plantation in Indonesia. Oil palm fronds are available daily throughout the year when the palms are cut during the harvesting of fresh fruit bunches for oil production. Each palm oil tree has more than one frond with $120 \mathrm{~cm}$ of length and approximately $10 \mathrm{~kg}$.

c. Empty Fruit Bunch (EFB). One of the palm oil extraction processes' primary residues is the empty fruit bunches (EFB), which are the fruit bunches' structural parts. Empty fruit bunches (EFB) are what remains of the fresh fruit bunches after the fruit has been removed for oil pressing. EFB is a ponderous and voluminous brown bunch leftover at palm oil mills. It is irregular in shape, weighs about $3.5 \mathrm{~kg}$, has a thickness of $130 \mathrm{~mm}$, and can vary from 170 to $300 \mathrm{~mm}$ long and 250-350 mm wide.

d. Mesocarp Fiber (MF). Palm oil mills produce mesocarp fiber (MF) and oil palm nut after screw-pressing of palm fruits during CPO production. Oil palm nut will undergo a further process, but MF will be allowed to pile up as fiber waste immediately. MF consists of strands of fiber with a length between $30 \mathrm{~mm}-40 \mathrm{~mm}$ and tends to be light brown.

e. Palm Kernel Shell. Palm kernel shells (PKS) are the shell fractions left. Subsequently, the nut has been removed after crushing in the Palm Oil mill. PKS is a fibrous material and can be easily handled in bulky conditions directly from the product line to the end-user. Large and small shell fractions are mixed with a dust-like fractions consistency along with tiny fibers. It has a brownish-yellow in color in particle sizes normally ranging between $5 \mathrm{~mm}$ and $40 \mathrm{~mm}$.

Figure 1: Process flow of oil palm tree plantation and mill production.

Source: author

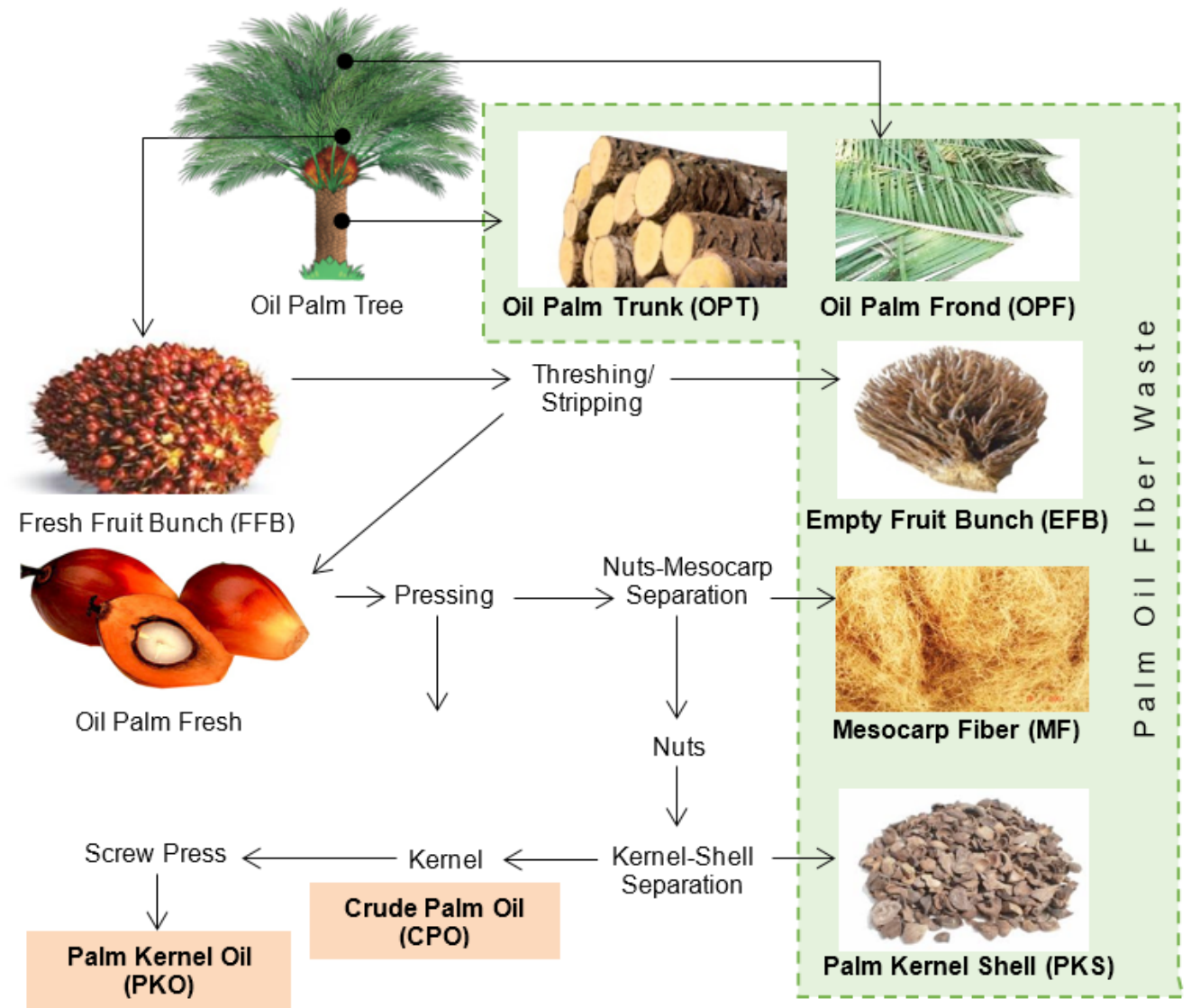


The palm oil plantation area's average growth for the period 1970-2017 reached 10.31\% per year (BPS Statistics Indonesia, 2017). Oil palm growth occurs not only in its area but also in the level of productivity per hectare of the plantation. On average, the Indonesian oil palm plantation productivity from 1995-2017 grew by 0.72\%/year (BPS Statistics Indonesia, 2017), 2017). Those growths are in accordance with the increasing production of fiber waste. In 2015, palm oil fiber waste reached the amount of; EFB: 30 million tons, PKS: 8.4 million tons, MF: 17.4 million tons, OPF: 124 million tons, and OPT: 34 million tons (Hambali \& Rivai, 2017). In other words, the total oil palm fiber waste in Indonesia in 2015 amounted to 213.80 million tons. Unfortunately, that number cannot be compared with national wood production figures (round or processed wood) in the same year because the unit used is cubic meters. However, if the comparative value is the production of wood pulp paper, the palm oil fiber waste figure looks very large because the national paper pulp production rate in 2015 was only 5.76 million tons (BPS Statistics Indonesia, 2016).

The oil palm fiber waste from the above data is not wholly unutilized. A small portion of the waste has been successfully re-utilized into other products or functions. PKS and MF wastes, for example, are used extensively as fuel for steam production in palm oil mills. EFB wastes have been converted into fertilizer used in oil palm plantations or other plantations. In addition to converting OPT to fertilizer, OPT can also be used to feed livestock on cattle farms. However, even though it has been able to be used as other products such as fertilizer, animal feed, etc., it turns out that all of the converted oil palm wastes cover only $10 \%$ of the total waste produced (Dungani et al., 2016). The rest remains as residual waste. Much of this residual waste then contributes to severe environmental problems when left in processing factories and farms (Dungani et al., 2016). For this reason, there is still a lot of palm oil fiber waste that has not yet been reprocessed and has the potential to be used as building materials for affordable house

\section{Palm Oil Tree Fiber Waste as Affordable House Building Materials}

The previous chapter's discussions show that oil palm fiber waste has a tremendous volume that remains untapped and can be converted as building materials. Therefore, the next step is to determine an appropriate technique for processing the palm fiber waste that may generate a renewable material that may support more affordable yet durable housebuilding materials.

Among all palm oil fiber waste, only the OPT can be directly processed into construction lumber through minimal modification effort. OPT lumber was already identified as a substitute material for rubberwood and other solid wood species because of its physical and mechanical properties, thermal stability, and high resistance to pests, such as termites (Suhaily et al., 2012). Nevertheless, until now, no one has tried to make OPT lumber as materials for building structures. Nonetheless, a previous study had proved that OPT lumber could be used as door/window frames and furniture frames (Erwinsyah, 2017)

If the OPT can be converted directly into ready-to-use lumber, other fiber wastes need to undergo a longer conversion process as a biocomposite material.

Biocomposite is a composite material formed by a matrix/resin and a reinforcement of natural material (Stark, Cai, \& Carll, 2010). Usually, natural material comes from lignocellulose, which is a widely available substance found in nature. This type of material needs to be breakdown into a smaller sized material before it can be finally formed into different biocomposite products such as; plywood, fiberboard, oriented strand board, and particleboard. Many previous studies have attempted to make palm oil fiber waste a primary material of biocomposite (See table 1). These studies have several general findings, including;

a. Particle size, geometry, type, and composition will affect biocomposite mechanical and physical properties (Hashim et al., 2011) (Sahari et al., 2014).

b. All kinds of Palm oil fiber waste can be used as a primary ingredients for all biocomposite types, but excluding plywood. Only OPT and its veneer type particle can be used as primary material for plywood (Abdul Khalil et al., 2010)

c. Matrix/resin that is commonly used to produce the biocomposite many uses the formaldehyde-based, which uses a hot- 
Natural Fiber Waste from Palm Oil Tree: An Overview of Potential Usage for Indonesia's Affordable House Building Materials

Widyarko, Naresworo Nugroho, Dalhar Susanto press method. However, some can use cold-press processes using conventional PC cement (Hermawan et al., 2001).

d. Biocomposite from several palm oil fiber waste can be produced using a binderless process or without involves any matrix/resin (Laemsak \& Okuma, 2000) (Boon et al., 2013).

e. Several previous studies managed to create a biocomposite palm oil fiber waste that complies with JIS (Japanese Industrial Standard) and ES (European Standard) (Laemsak \& Okuma, 2000) (Boon et al., 2013).

The above findings confirm that palm oil fiber can be reprocessed as lumber or biocomposite, which is commonly used in building components.

In Indonesia, plywood is the only lignocellulosebased biocomposite that seems to be the most popular and widely used for building construction. Plywood is generally used as non-

Table 1: Biocomposite Research on Palm Oil Fiber Waste structural parts in Indonesia's building, mainly as a cover material for interior walls or ceilings. Simultaneously, particle boards and fiberboard (HDF and MDF) tend to be known as a material for furniture parts. These building materials tend not to be used for exterior usage because, for Indonesian, they are considered vulnerable to damage due to excessive outdoor weather. This perspective is unfortunate because the previous study proved that the suitable preservation method, either the naturallytraditionally method or the chemical method, can keep lignocellulose-based material away from undesirable damage from hot and humid climate (Putri \& Dewi, 2020).

One factor that may determine the preservative level is the type of resin/matrix when forming the biocomposite. Adding resins such as phenolic-based resins and isocyanates had proven to be able to produce biocomposite for outdoor purposes (Stark et. al, 2010). the Previous investigation had also validated that by using phenol-based resins, palm fiber waste

\begin{tabular}{|c|c|c|}
\hline $\begin{array}{c}\text { Palm Oil Fiber } \\
\text { Waste }\end{array}$ & Previous Research And Its Description & Sources \\
\hline \multirow[t]{2}{*}{ OPF } & $\begin{array}{l}\text { Particle Board made from OPF using steam-exploded binder less pro- } \\
\text { cess. The board's density and thickness swelling test results met the } \\
\text { requirement of JIS A 5908. }\end{array}$ & (Laemsak \& Okuma, 2000) \\
\hline & $\begin{array}{l}\text { Cold-pressed Particle Board made from OPF mixed with cement } \\
\text { PC (Portland Cement) as the adhesive and } \mathrm{CO} 2 \text { gas as the curing } \\
\text { treatment method. The mechanical and dimensional properties of the } \\
\text { board followed by } \mathrm{C} 02 \text { curing treatment improved significantly. }\end{array}$ & (Hermawan et al., 2001) \\
\hline \multirow[t]{3}{*}{ OPT } & $\begin{array}{l}\text { Experimental particleboard was manufactured using fine particles of } \\
\text { OPT using a binderless process. The panel's internal bond strength } \\
\text { meets the JIS standard, while the MOR did not. This research sug- } \\
\text { gests that adding an increase in temperature during pressing may } \\
\text { improve the properties of the boards. }\end{array}$ & (Hashim et al., 2011) \\
\hline & $\begin{array}{l}\text { Experimental binderless particleboards produced from several pro- } \\
\text { cessing parameters that include pressing temperatures, hot pressing } \\
\text { times and pressing pressures. The panel's thickness swelling nearly } \\
\text { met European Standard (ES) requirement for use in humid conditions. } \\
\text { Some of the specimens showed promising mechanical properties and }\end{array}$ & (Boon et al., 2013) \\
\hline & met the requirement of the European Standard. & \\
\hline OPT and EFB & $\begin{array}{l}\text { Hybrid plywood made from EFB and OPT with phenol and urea-form- } \\
\text { aldehyde resins. This type of plywood can be used in both interiors } \\
\text { and exterior and can be a substitute for conventional plywood. }\end{array}$ & (Abdul Khalil et al., 2010) \\
\hline \multirow[t]{2}{*}{ EFB } & $\begin{array}{l}\text { HDF made of EFB with formaldehyde resin. Based on the research, } \\
\text { the high-density fiberboard's mechanical properties show an increase } \\
\text { with increasing EFB proportion. The results show that the tensile and } \\
\text { hardness strength was higher than other existing composites mate- } \\
\text { rial. }\end{array}$ & (Sahari et al., 2014) \\
\hline & $\begin{array}{l}\text { MDF made from pre-treated EFB with phenol-formaldehyde resin. } \\
\text { Pre-treatment of EFB fiber to remove its residual oil significantly im- } \\
\text { proved the MDF performance in both mechanical and physical prop- } \\
\text { erties and eliminated delamination. }\end{array}$ & (Ramli et al., 2002) \\
\hline
\end{tabular}


in the form of OPT and EFB can be formed into biocomposite for exterior needs (Abdul Khalil et al., 2010). In other words, as a biocomposite, palm oil fiber waste indeed can be transformed as a building material for both interior and exterior uses in affordable house construction. At that time, virgin timber was recommended for use in affordable houses programs since its availability was still abundant in Indonesia. Nevertheless, in the present day, good quality timber that fits for building construction has become rare (Susanto \& Widyarko, 2017). Indonesia's long history of over-reliance on wood products has made the rate of forest destruction uncontrollable in this country. Even if wood derivatives products still exist in the market, it is too costly to be applied for affordable house programs. This is quite unfortunate because, based on the previous discussion; palm oil fiber waste has the potential to be renewable materials and virgin wood substitute. Not only that, using biocomposite with a non-wood base material as an alternative to conventional wood undoubtedly will help decrease the rate of global deforestation (Suhaily et al., 2012)

Consequently, by using the construction scheme in the RSH affordable house program released in 2002, palm oil fiber waste should be able to displace conventional wood in most of its parts, such as; roof structures, wall frames, wall covers, doors, and windows (see figure 2). Indonesia's building construction technology is lagging behind other countries, especially in using waste products from the agro-industry for building construction purposes. Strawbale, as building materials, is one of the examples. Straw bale is the bundle of stalks left after the edible part of the grain had been harvested (such as wheat or rice). Since the beginning of the 21st century, contemporary straw-bale houses are reappearing in the world. Utilizing this agro-waste for building materials had successfully made the building maintain a low embodied energy value and excellent thermal performance during both winter and summer (Douzane et al., 2016). The straw bale house's story above should be an example for Indonesia on how to adapt to new building material. That is why there is no reason to halt implementing palm oil fiber waste as building materials, especially for the purpose of building an affordable house. Therefore, the burden of Indonesia's never-ending housing backlog problems should be eased by converting its over-abundant palm oil fiber waste as its building materials to new renewable sources.

Figure 2: Indonesia's Construction Scheme in the RSH Affordable House Program Source: Author

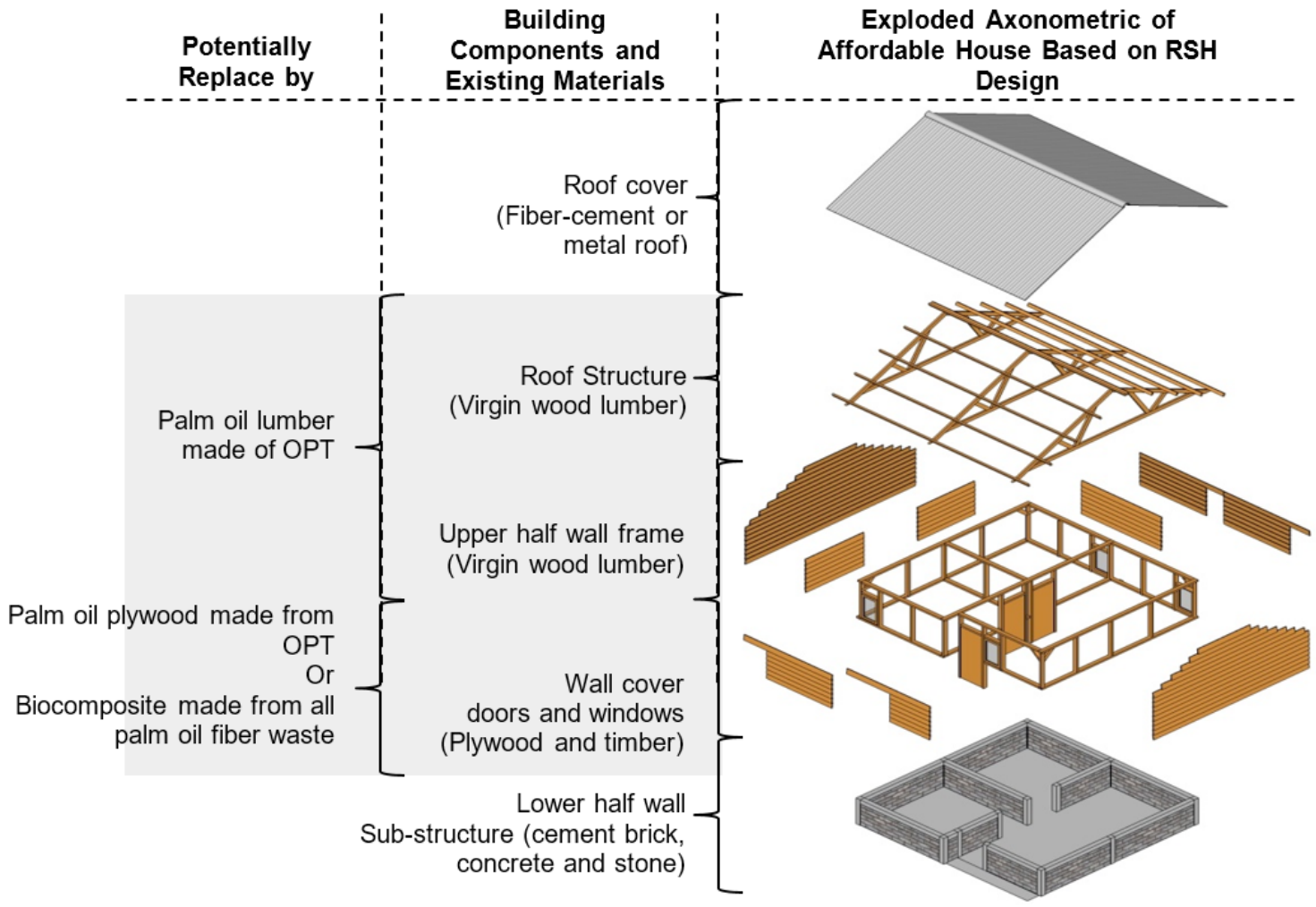


Natural Fiber Waste from Palm Oil Tree: An Overview of Potential Usage for Indonesia's Affordable House Building Materials

Widyarko, Naresworo Nugroho, Dalhar Susanto

\section{Conclusion}

Palm oil fiber waste produced in Indonesia's palm oil industry consists of Oil Palm Trunk (OPT), Oil Palm Frond (OPF), Empty Fruit Bunch (EFB), Mesocarp Fiber (MF), and Palm Kernel Shell (PKS). Until now, most of the residual waste is still underutilized, and the sheer quantity of this waste contributes to severe environmental problems when left in processing factories and farms. Prior studies had shown that most of this fiber waste could be converted into building materials such as construction lumber and biocomposites either for indoor or outdoor purposes. On the other hand, the Indonesian housing backlog issues have never been solved over decades. By using the government's affordable house design in 2002, building materials from recycled palm oil fiber waste should be able to substitute conventional/virgin wood that was planned to be used in the house. Hence, realizing this proposal should reduce both the housing shortage and the environmental issues caused by palm oil fiber waste. The author is aware that future studies are still needed to verify this hypothesis, knowing that utilizing waste from massive agro-industries and implementing it into the national affordable house program would require numerous reviews from diverse academic aspects.

\section{References}

Abdul Khalil, H. P. S., Nurul Fazita, M. R., Bhat, A. H., Jawaid, M., \& Nik Fuad, N. A. (2010). Development and material properties of new hybrid plywood from oil palm biomass. Materials and Design, 31(1), 417-424. https://doi.org/10.1016/j. matdes.2009.05.040

Boon, J. G., Hashim, R., Sulaiman, O., Hiziroglu, S., Sugimoto, T., \& Sato, M. (2013). Influence of processing parameters on some properties of oil palm trunk binderless particleboard. European Journal of Wood and Wood Products, 71(5), 583589. https://doi.org/10.1007/s00107-0130712-5

BPS Statistics Indonesia. (2016). Statistics of Forestry Production 2015. BPS Statistics Indonesia.

BPS Statistics Indonesia. (2017). Indonesian Oil Palm Statistic 2017. BPS Statistics Indonesia.
Douzane, O., Promis, G., Roucoult, J. M., Tran Le, A. D., \& Langlet, T. (2016). Hygrothermal performance of a straw bale building: In situ and laboratory investigations. Journal of Building Engineering, 8(October), 91-98. https://doi.org/10.1016/j.jobe.2016.10.002

Dungani, R., Karina, M., Subyakto, Sulaeman, A., Hermawan, D., \& Hadiyane, A. (2016). Agricultural waste fibers towards sustainability and advanced utilization: A review. Asian Journal of Plant Sciences, 15(1-2), 42-55. https://doi.org/10.3923/ ajps.2016.42.55

Erwinsyah. (2017). The Use of Oil Palm Trunk for Commercial Product. October, 18-20.

Hambali, E., \& Rivai, M. (2017). The Potential of Palm Oil Waste Biomass in Indonesia in 2020 and 2030. IOP Conference Series: Earth and Environmental Science, 65(1). $\quad$ https://doi.org/10.1088/17551315/65/1/012050

Hashim, R., Said, N., Lamaming, J., Baskaran, M., Sulaiman, O., Sato, M., Hiziroglu, S., \& Sugimoto, T. (2011). Influence of press temperature on the properties of binderless particleboard made from oil palm trunk. Materials and Design, 32(5), 2520-2525. matdes.2011.01.053

Hermawan, D., Subiyanto, B., \& Kawai, S. (2001). Manufacture and properties of oil palm frond cement-bonded board. Journal of Wood Science, 47(3), 208-213. https:// doi.org/10.1007/BF01171223

Kompas.com. (2018). Perbankan Tolak KPR 30000 Rumah Subsidi. Retrived from https://properti.kompas.com/ $\mathrm{read} / 2018 / 02 / 08 / 162422921 /$ perbankantolak-kpr-30000-rumah-subsidi

Kusno, A. (2012). Housing the Margin: Perumahan Rakyat and the Future Urban Form of Jakarta. Southeast Asia Program, Cornell University. https://muse.jhu.edu/ article/488360

Laemsak, N., \& Okuma, M. (2000). Development of boards made from oil palm frond II: Properties of binderless boards from steam-exploded fibers of oil palm frond. Journal of Wood Science, 46(4), 322-326. https://doi.org/10.1007/BF00766224

Lubis, A. U. (2008). Kelapa Sawit (Elaeis guineensis Jacq.) Di Indonesia (2nd ed.). Indonesian Oil Palm Research Institute.

Pandelaki, E. E., \& Shiozaki, Y. (2010). the Core House Concept and Its Implementation in. Int. Journal for Housing Science, 34(4), 
233-248.

PUPR. (2001). Sekilas Perumahan dan Permukiman di Indonesia, Kementrian Pekerjaan Umum dan Perumahan Rakyat.

PUPR. (2016). Kementerian PUPR Siapkan Empat Strategi Penyediaan Perumahan. PU-NET. https://www.pu.go.id/berita/ view/10648/kementerian-pupr-siapkanempat-strategi-penyediaan-perumahan

PUPR. (2019). Realisasi Program Sejuta Rumah Hingga 5 Agustus 2019 Capai 735.547 Unit. PPDPP. https://ppdpp.id/ realisasi-program-sejuta-rumah-hingga-5agustus-2019-capai-735-547-unit/

Putri, A. H., \& Dewi, O. C. (2020). Overview of Bamboo Preservation Methods for Construction Use in Hot Humid Climate. International Journal of Built Environment and Scientific Research 4(1), 1-10. https:// doi.org/10.24853/ijbesr.4.1.1-10

Ramli, R., Shaler, S., \& Jamaludin, M. A. (2002). Properties of Medium Density Proper Operties Fiberboard From Oil Palm Empty. Journal of Oil Palm Research, 14(2), 34-40.

Sahari, J., Nuratiqah, M. N., \& Rao, M. M. (2014). Developing and Prototyping of Empty Fruit Bunch High Density Board. Journal of Advance Research Design, 3(1), 1-8.

Snyder, H. (2019). Literature review as a research methodology: An overview and guidelines. Journal of Business Research, 104(March), 333-339. https://doi. org/10.1016/j.jbusres.2019.07.039

Stark, N. M., Cai, Z., \& Carll, C. (2010). Woodbased composite materials panel products, glued-laminated timber. In Structural Composite Lumber, and Wood-Nonwood Composite Materials. Wood handbookWood as an engineering material. General Technical Report FPL-GTR-190. Madison, WI: U.S. Department of Agriculture.

Suhaily, S. S., Jawaid, M., Abdul Khalil, H. P. S., \& Ibrahim, F. (2012). A review of oil palm biocomposites for furniture design and applications: Potential and challenges. BioResources, 7(3), 4400-4423. https:// doi.org/10.15376/biores.7.3.4400-4423

Susanto, D., Nuraeny, E., \& Widyarta, M. N. (2020). Rethinking the minimum space standard in Indonesia: tracing the social, culture and political view through public housing policies. Journal of Housing and the Built Environment, 35(3), 983-1000. https://doi.org/10.1007/s10901-020-
09770-4

Susanto, D., \& Widyarko, W. (2017). Sustainable Material : Used Wood As Building Material. Insist, 2(1), 14. https://doi.org/10.23960/ ins.v2i1.26

Varkkey, H. (2012). The Growth and Prospects for the Oil Palm Plantation Industry in Indonesia. Oil Palm Industry Economic Journal, Vol 12(No.2), 1-13. 